\title{
ANAEMIA AND POLYCYTHAEMIA WITH RENAL DISEASE
}

\author{
David G. Penington, M.A., B.M., M.R.C.P. \\ (From the Pratt Clinic, New England Center Hospital, and the Department of Medicine, Tufts University \\ School of Medicine, Boston, Massachusetts)
}

\begin{abstract}
ANæeMIA has long been recognized as a feature of renal failure but the relation between renal function and the bone marrow has been slow to unravel. Much has been learned in this field in recent years, but a great deal remains unexplained, and the anæmia continues to defy all treatment short of transfusion.
\end{abstract}

\section{Red Cell Morphology in Renal Anæmia}

In early studies by Ashe (1929) and Parsons and Ekola-Strolberg (1933) the anæmia was found to be associated with erythrocytes normal both in size and hæmoglobin content. A striking feature was the absence of any disturbance of white cells or platelets. Studies of bone marrow morphology by Dameshek (1935) and Nordenson (1938) revealed the same pattern. Erythropoiesis appeared qualitatively normal, but red cell precursors were markedly reduced in numbers. Nordenson recorded the interesting and apparently paradoxical finding that the erythroid precursors showed a normal incidence of mitoses despite the reduced number of these cells. This observation takes on a new significance in the light of recent studies of the causes of this bone marrow depression. Gingold, Comsa and Roman-Crivat (1938) found evidence of increasing aplasia of the marrow as renal failure progressed but the hæmoglobin level correlated poorly with urea retention. Some investigators, on the other hand, found no indications of defective erythropoiesis, assessed by marrow biopsy, an actual increase in number of normoblasts being noted on occasions (Scott, I939; Callen and Limarzi, 1950), which would suggest either arrested maturation without morphological abnormality, or decreased life span of the red cell as the cause of the anæmia.

\section{Hæmolysis and Red Cell Life Span in Renal Anæmia}

In patients with acute renal failure and less commonly in terminal uræmia, a fall in hæmoglobin level may occur which is too rapid to be attributed to defective red cell production. Uræmia may be associated with a marked bleeding tendency, and concealed hæmorrhage may contribute to the anæmia in some cases. However, there is now clear evidence that red cell survival may be reduced in some cases of renal anæmia in the absence of detectable bleeding, the usual inference being that hæmolysis occurs. The occasional appearance of gross morphological changes in red cells in acute uræmia, the 'burr cells' of Schwartz and Motto (1949), supports this view, but the hallmarks of hæmolysis-hyperbilirubinæmia, increased urobilinogen excretion, or reticulocytosis-are not found (Loge, Lange and Moore, 1958). Red cell life span has been estimated in renal anæmia using the Ashby crosstransfusion technique (Emerson and Burrows, 1949; Chaplin and Mollison, 1953; Loge, Lange and Moore, 1950 and 1958) and using a radioactive chromium label for the patients' own red cells (Sutherland, McCall, Jones and Muirhead, I955; Joske, McAlister and Prankerd, 1956; Rees, Scheitlin, Pond, McManus, Guild and Merrill, 1957; Verel, Turnbull, Tudhope and Ross, 1959). In each of these studies shortening of red cell survival was demonstrated in some patients although many of the studies are open to criticism on technical grounds as care was not taken to exclude artifacts due to changing plasma volume or red cell mass during the period of observation. (The former is likely to be of considerable importance in acute or terminal renal failure, leading to dilution of labelled cells per unit volume of blood; the criticism applies to both the radiochromium and Ashby methods as usually carried out.) Shortening of erythrocyte life span in renal anæmia may, in fact, be considerably less common than reported in the earlier studies. Verel and others (1959) used the radiochromium technique with repeated estimation of red cell volume (employing a second isotope, radioactive phosphorus) and found a shortened red cell life span in only five of 40 patients with anæmia associated with nephritis, one being a patient with coexistent Hodgkins disease, which may have been the cause of the hæmolysis. Of the five patients with shortened red cell survival, three showed 
malignant hypertension with papillœdema, and a fourth was in terminal uræmia. Whether the shortened life span was due to intravascular hæmolysis or could have been attributed to extravasation of red cells into tissues (consequent on widespread vasculitis) could not be determined. It is of considerable interest, however, that in one patient with malignant essential hypertension, anæmia was associated with shortened red cell survival, despite a normal blood urea; effective treatment of the hypertension was followed by a return of the hæmoglobin level and the red cell survival to normal.

The studies of a number of investigators have indicated that the shortening of red cell survival is due to extracorpuscular factors rather than to a red cell defect. Chaplin and Mollison (1953) and Loge and others (1958) observed that whilst the survival of erythrocytes from normal donors was shortened in patients with renal anæmia, red cells from the uræmic subjects survived normally in healthy recipients. Rees and others (1957) studied the effect of artificial dialysis on red cell life span in chronic renal failure and found that the rate of destruction of erythrocytes returned towards normal four to six days after dialysis. Muirhead, Stirman and Jones (1960) reported that bilaterally nephrectomized dogs maintained by peritoneal lavage showed a marked shortened red cell survival, but that this was corrected by explantation of renal medullary tissue to the peritoneal cavity. These remarkable observations are difficult to evaluate; from the studies in human subjects it would appear that the defect is correctable by dialysis but it remains unknown whether a toxic factor operates directly on the circulating erythrocyte, or whether the process is indirect, damaging vascular endothelium with consequent extravasation of red cells into the tissues. Possibly both processes play a part under certain conditions.

Hæmolysis may clearly contribute to the anæmia of renal disease, but it has been found principally in patients with acute or terminal uræmia, or with malignant hypertension. It is unlikely that it plays a major role in the anæmia associated with other stages of chronic renal disease, where defective red cell production appears to be the primary disorder.

\section{Isotopic and Chemical Studies of Erythro- poiesis}

The use of the radioactive iron isotope ${ }^{59} \mathrm{Fe}$ has largely confirmed the earlier morphological studies of erythropoiesis. Thus Finch, Gibson, Peacock and Fluharty (1949), Loge and others (1950 and 1958), and Joske and others (1956) all demonstrated markedly decreased red cell production in chronic renal failure.
Evidence of iron deficiency is seldom found in such patients (Cartwright, Huguley, Ashen brucker, Fay and Wintrobe, 1948; Loge an $\$$ others, 1958; Verel and others 1959) and when present is likely to be conicidental. Cartwright and others (1948) found elevation of free erythro: cyte protoporphyrin in six of seven patients wit uræmic anæmia, a finding similar to that in othe anæmias with defective erythropoiesis, but change. in plasma iron, iron-binding capacity or coppe? levels typical of toxic marrow depression as seepp in infection or heavy metal intoxication were no $\overrightarrow{5}$ observed. Loge and others (1948) could detects significant elevation of free erythrocyte protos porphyrin in only eight of 2 I patients with rena anæmia, and such elevation could not be cors related with the serum iron level, the degree off azotæmia, or the severity of the anæmia. In the light of this evidence it would be difficult to attribute the undoubted defect in red cell pros duction in uræmia to simple toxic depression of erythropoiesis. Recent experimental studies haveo however, implicated the kidney in the physiological regulation of erythropoiesis, and have opened $\infty$ new approach to the problem of anæmia in rena failure.

\section{Relation of the Kidney to Erythropoiesis}

\section{The Humoral Hypothesis}

Our understanding of the mechanisms by when the body finely regulates the production of red cells to meet its requirements for oxygen transpor is still very inadequate. A great impetus to the study was provided by Erslev (1953) and Borsook Graybiel, Keighley and Windsor (I954), who were able to demonstrate that the plasma of anæmio animals contained a humoral factor capable of stimulating erythropoiesis in normal recipients This humoral factor, now usually known as 'erythropoietin', has, to date, eluded chemicas isolation, but a considerable body of evidence has. accumulated to indicate that it is a specific entity chemically a mucoprotein, stimulating erythros. poiesis in experimental animals when adminis tered in extremely small quantities (Goldwasser 1962). It affects the bone marrow principally by inducing differentiation of very immature marro cells, possibly multipotential hæmocytoblasts, to: subsequent maturation through the erythroif series. It does not constitute a stimulus, at least primarily, to mitosis or to hæmoglobin synthesi\$, these functions being governed, apparently, by processes within the normoblast itself, or by other factors originating within the marrow.

The extent to which erythropoietin regulates the day-to-day production of red cells in health if unknown. The hormone has been demonstrated 
in normal rat (Reichlin and Harrington, 1960) and human plasma (Penington, 1962), but following transfusion of a normal human subject, slowing of erythropoiesis was found to precede the disappearance of erythropoietin from plasma, suggesting that factors other than the hormone must play some part in controlling normal bone marrow activity.

In patients with anæmia, Van Dyke, Layrisse, Lawrence, Garcia and Pollycove (I96r) were able to detect the plasma hormone in iron deficiency when the hæmoglobin had fallen below approximately $5 \mathrm{~g} . \%$, raising the possibility that the erythropoietin system represents a 'feed-back' mechanism brought into operation by profound anæmia rather than a system for the physiological regulation of erythropoiesis. However, employing a more sensitive assay procedure, an increase in titre of the hormone has been demonstrated in the plasma of a normal subject following venesection, when the hæmoglobin level was greater than 12 g. $\%$ (Penington, 196r) indicating the participation of the hormone in the red cell regeneration following moderate hæmorrhage, and it may be concluded that the absence of the hormone from plasma in anæmic states would be of significance in the ætiology of an anæmia. The validity of any such conclusion, however, depends on the limitations of sensitivity of the assay procedure employed. To date, in no form of anæmia has a subnormal titre of the hormone been demonstrated in plasma, and claims which have been made for the role of defective production of the hormone in the rtiology of anæmia have been based on less definitive evidence.

\section{Physiological Studies of Erythropoietin Production in Animals}

The site of production of the hormone in the body has been the subject of considerable controversy. Contopoulos, Ellis, Simpson, Lawrence and Evans (1954) demonstrated that the pituitary elaborated a factor capable of stimulating erythropoiesis in the hypophysectomized animal. However, hypophysectomized rats were found to respond to bleeding with increased erythropoiesis (Jacobson, Plzak, Fried, and Goldwasser, I956) and the pituitary factor was subsequently shown to be identical with ACTH (Simpson, Evans and Rosenberg, 1959), operating via the adrenal to increase the rate of metabolism in the hypophysectomized animal, and hence to increase its requirement of red cells for oxygen transport. There is no convincing evidence to indicate that ACTH plays a physiological role in the regulation of erythropoiesis in the intact animal.

Stohlman, Rath and Rose (I954) studied a patient with regional hypoxia of the lower half of the body resulting from a patent ductus arteriosus with pulmonary hypertension and reversal of flow through the shunt. Polycythæmia had developed despite normal oxygenation of the upper trunk, head and arms, suggesting that some organ or organs in the lower part of the body were capable of secreting the humoral factor leading to polycythiemia. Jacobson, Goldwasser and their collaborators (Jacobson, Goldwasser, Fried and Plzak, 1957; Goldwasser, Fried and Jacobson, 1958; Jacobson, Marks, Gaston and Goldwasser, 1959) found that removal of many of the endocrine glands and viscera in the rat did not deprive the animal of the capacity to produce erythropoietin in response to bleeding, but that, when the kidneys were removed, increased production of the hormone could not be detected with certainty in response to bleeding, hypoxia or cobalt administration. Comparable uræmia, induced by bilateral ligation of the ureters, did not impair hormone production. Mirand and Prentice (1957) failed to confirm that nephrectomy in the rat inhibited production of the hormone, but their assay of erythropoietin was carried out in hypophysectomized animals in which ACTH and corticoids (released in the donor animals in response to hæmorrhage or anoxia) might be expected to increase erythropoiesis. Reissman, Nomura, Gunn and Brosius (1960) more recently confirmed that bilateral ligation of the ureters in the rat does not impair the normal erythropoietic response to anæmia, whereas bilateral nephrectomy or tubular necrosis induced with mercuric chloride do abolish this response. Injection of erythropoietin accelerates erythropoiesis in nephrectomized rats but to a lesser extent than in normal animals or in those in which the ureters have been ligated.

Whilst, in the rat, the kidney appears to be essential for the normal increase in hormone production in response to anæmia, there is now mounting evidence of species differences. In the dog, Naets (1958) observed disappearance of normoblasts from the marrow following bilateral nephrectomy with virtual cessation of erythropoiesis, whereas obstructive uræmia had little effect on bone marrow function. In the rabbit, on the other hand, Erslev (1958) found that both bilateral ligation of the ureters and nephrectomy abolished the increase in plasma erythropoietin following hæmorrhage, and the uræmic rabbits showed impaired bone marrow response to administered erythropoietin whether or not functioning renal tissue remained. This would suggest that uræmia itself depresses erythropoiesis. Fischer and Friederici (196I) made the important observation that normoblasts were preserved in the bone marrow of bilaterally nephrectomized rabbits maintained for considerable periods by peritoneal lavage. These findings strongly suggest sites of 
production of erythropoietin outside the kidney. Kuratowska, Lewartowski and Michalak (196I) have demonstrated erythropoietin production by the isolated perfused rabbit kidney, but more recently Reissman (1962), also studying the rabbit, was able to demonstrate that both the isolated kidney and liver could produce an erythropoiesisstimulating factor under conditions of hypoxia, provided careful attention was paid to the maintenance of a physiological $p \mathrm{H}$ in the perfusion system. The weight of evidence from such studies would, therefore, favour the view that the hormone may be derived from several organs although of these the kidney may be the most important.

\section{Erythropoietic Activity of Tissue Extracts}

Early attempts to demonstrate erythropoietic activity in extracts from normal tissues met with no success (Gordon, Piliero and Tannenbaum, 1955; Erslev, 1958; Rambach, Alt and Cooper, 1957). Naets (1960) found that homogenates of anæmic dog kidney significantly stimulated erythropoiesis in a rat in which erythropoiesis was slowed by starvation, but as erythropoietin is excreted in the urine when the plasma titre is high, and may be reabsorbed by the tubules, such a demonstration of the hormone in the anæmic kidney is of doubtful significance. Slight stimulation of erythropoiesis by homogenates of liver and spleen were attributed to the supply of nutrients with the material assayed. Rambach, Alt and Cooper (196I) recently found that injection of washed homogenates obtained from a wide variety of normal rat tissues led to stimulation of erythropoiesis in their assay animals (in this instance, rats with relative polycythæmia induced by dehydration); it should be noted that injection of these insoluble tissue-homogenates produced considerable local inflammatory reaction in the assay animals, and the mechanism by which erythropoiesis was stimulated is far from clear. Recently, however, soluble protein preparations have been obtained from liver, spleen and kidney of normal rats and dogs, and from the kidneys of slaughterhouse pigs, which stimulate erythropoiesis in an assay animal in which red cell production has been slowed by transfusion (Penington, unpublished), and it appears likely that many tissues are capable either of elaborating erythropoietin, or stimulating its elaboration elsewhere within the body. Whether this apparently widespread tissue factor and the mucoprotein hormone of anæmic plasma are identical has not been established; it must be borne in mind that the demonstration of erythropoietic activity in tissue extracts, particularly if associated with insoluble particulate matter as found by Rambach, cannot be accepted as evidence that each of these tissues is capable of influencing red cell production under physiologicaf conditions. The tissue factor, however, whethes the same or different from that of anæmic plasma may have great relevance to the occasional oc $\div$. currence of polycythæmia with primary tumour of a number of organs-kidney, ovary, uterus? liver, cerebellum and mesencephalic region: Further chemical studies of this tissue factor wils be required to establish its relation to the्户 physiological hormone.

\section{Site of Production of Erythropoietin in Man}

Studies of erythropoiesis in a human subject maintained by artificial dialysis following surgicad extirpation of a sole remaining kidney showes that erythropoiesis may continue at something approaching a normal rate (Rees, Scheitlin.e. Giordano, Guild and Merrill, I960). In thi\$\$ respect, therefore, man resembles the rabbit mor $\$$ closely than the dog or the rat, the kidney not being essential for the maintenance of normal erythoid activity. It would be of great interest to know whether the plasma of such a patient contains the physiological erythropoietic hormone, and whethers such a patient could respond to a physiologicas stimulus to erythropoiesis. This would establis whether extrarenal sites of production of hormone exist in man, or whether the erythroid marrow is capable of some degree of autonom@is activity. Fortunately, opportunities for suftes studies are rare, but in so far as it is ever justifiatile to infer patterns of human physiology from studie@ in experimental animals it appears likely that whils a number of organs have the capacity to elaborate an erythropoiesis-stimulating hormone, undef conditions of anæmia the kidney appears to be the most sensitive to the reduced oxygen carrying capacity of the blood. The reason for this primary role of the kidney lies, almost certainly, i the pattern of the renal vasculature and its re sponse to anæmia. Both Bradley and Bradle (1947) and Baldini and Lamperi (1956) found that in chronic anæmia the renal plasma flow is main 3 . tained at a normal rate, the total renal blood flow falling with the hæmatocrit, further reducing the number of red cells reaching the renal tissue.

The kidney would appear, therefore, to be the organ with the highest threshold to defectiv oxygen supply and its vasculature is such that the stimulus of anæmia is ' amplified' as the hæmoळ globin level falls, leading to the greatly increased outpuring of erythropoietin found at low hæmo^ globin levels.

\section{Erythropoietin in Renal Anæmia}

Assay methods used in the study of erythro@ poietin in anæmia have been extremely varied The intact animal shows little increase in erythro 0 
poiesis following the administration of small doses of ' anæmic' plasma, and reticulocytosis, a sensitive but capricious index of erythropoiesis, must be used to detect the changes. Results obtained using this method have differed from those of other techniques (Linman and Bethell, 1956; Osnes, 1959; Clotten and Clotten, 1959), and judgment on such observations should be reserved until the variety of factors which appear to influence reticulocytosis are better understood. In many instances conclusions have been drawn from very slight elevation in reticulocyte counts, and much must depend upon the impartiality of the observer.

Techniques which lessen the endogenous stimulus to erythropoiesis in animals have been employed by many investigators to improve the sensitivity to administered erythropoietin. Here again, however, errors have been introduced. The most widely used procedures have been hypophysectomy or acute starvation, both of which markedly slow erythropoiesis, presumably reflecting reduced tissue requirements for oxygen (Fried, Plzak, Jacobson and Goldwasser, 1957) but in each instance, hormones other than erythropoietin may well influence the assay findings. A more specific, and more sensitive method has been that in which animals - rats or mice-have been rendered polycythæmic by transfusion (Fried and others, 1957; Gallagher, McCarthy and Lange, 1960; Penington, I96I) or by exposure to low oxygen tension (Cotes and Bangham, 196I) following which the plethoric animals lack any physiological stimulus to erythropoiesis. Radioactive iron has provided the most widely used method of measuring the rate of erythropoiesis in the animals following one or two injections of the material for assay. Quantitative assessment of the hormone in plasma remains crude, however, and conclusions concerning defective production of the hormone in disease have been based on a comparison of findings in anæmia due to different causes. There is now a growing body of evidence to indicate that in the anæmia of renal failure the hormone titre is elevated to an extent considerably less than that observed in other types of anæmia of comparable severity (Gurney, I957; Gallagher and others, 1960; Penington, 196r). Whilst it would be tempting to conclude that lack of erythropoietin is the sole cause of defective erythropoiesis in renal failure, further studies do not confirm this view. With chemical concentration of the hormone from plasma, some increase in titre is found in renal anæmia when compared with similar concentrates of normal plasma (Penington, 1961).

It may be concluded, therefore, that in chronic renal disease several factors, including hæmolysis, and most probably toxic marrow depression conspire to produce anæmia, but that the normal increase in erythropoietin titre in response to anæmia is lacking. The relative importance of these various factors in the ætiology of the anæmia must await the availability of the hormone for clinical trials.

\section{Nature of the Tissue Receptor for Erythro- poietin Release-A Hypothesis}

The arterial tree contains specialized tissues such as the carotid body sensitive to anoxia of arterial blood, but secretion of erythropoietin occurs with a fall in oxygen content of blood, for in anæmia the arterial oxygen tension is normal. Whilst reduced oxygen tension in arterial blood also constitutes a stimulus to erythropoietin secretion, the common factor to anæmia and hypoxia would appear to be reduced oxygen supply to some sensitive tissue, the final common pathway being lowered tissue oxygen tension.

Osnes (1958), from studies in mice, suggested that renal juxtaglomerular granules might represent the site of production of the hormone, these granules increasing in number with hæmorrhage and disappearing following transfusion. However, these experimental procedures would be expected to cause great alterations in juxtaglomerular granulation accompanying altered secretion of renin (known to be derived from this tissue). Furthermore, these cells, situated as they are in the afferent and efferent arterioles of the glomerulus, are bathed by arterial blood, in which oxygen tension is normal in anæmia. It would appear unlikely, therefore, that they would be capable of ' recognizing' anæmia in the arterial blood.

The vascular structure of the nephron does, however, provide a mechanism whereby the body can readily translate 'oxygen content of blood' to 'altered tissue tension'. After leaving the glomerulus, blood passes along the course of the proximal convoluted tubule and loop of Henle to the distal tubule, oxygen - being extracted to an extent dependent on the rate of metabolism of the tubular cells. If, when blood reaches the distal tubule, the oxygen content has been depleted below a critical level, production or release of the hormone would be initiated. The latent interval of some three to six hours which has been observed between the exposure of an animal to hypoxia and the appearance of the erythropoietin in plasma would suggest that the response to the stimulus is not simply one of release of preformed hormone. The steps involved in the release of the hormone are of considerable interest, but remain to be clarified. Papain, a plant enzyme similar in substrate specificity to several tissue hydrolytic enzymes (cathepsins) and like them activated by 
reducing conditions, is known to stimulate erythropoiesis when injected into rats (Yen, Cheng-Chun Lee and Flemming, 1960) although it destroys erythropoietin in vitro. The step linking tissue hypoxia with liberation of the hormone may well be provided by such an enzyme, activated by reducing conditions in the tubular cells, converting a hormone precursor to an active form. Preliminary studies using tissue preparations suggest that such a step is involved. The localization of this humoral function in the nephron remains unknown. It may be a property of the tubule as a whole, or of a specialized region of the distal tubule such as the macula densa, or the granular ' intercalated cells' proximal to the collecting tubule. Perhaps the latter would be the most favourably situated to function as a regulator of erythropoiesis.

The hypothesis outlined above has a number of interesting corollaries. Removal of oxygen from blood perfusing the nephron will be governed by the metabolic requirements of the tubular cells. Increased oxygen extraction by stimulation of cell metabolism should constitute a stimulus to erythropoietin secretion, as shown by Fried and others (1957) using dinitrophenol, an agent known to uncouple oxidative phosphorylation in the tissues. Reduction of metabolic rate should be accompanied by reduced hormone secretion and it). has been suggested by Jacobson and others (r959) that the reduction in erythropoiesis following acute starvation or in myxœdema reflects such a change. The anæmia of myxœdema in man, however, represents a more complex disturbance (Penington, unpublished).

Factors influencing the rate of perfusion of the nephron should greatly affect erythropoietin secretion. Thus, as nephrons are obliterated by disease, an increased rate of perfusion of remaining nephrons would lead to a constant 'overestimation' of the oxygen content of the blood, and a 'resetting' of the homeostatic level for erythropoiesis at a point well below the normal hæmoglobin concentration. The erythropoietic defect in chronic renal disease might, therefore, be one of an altered threshold for erythropoietin secretion, rather than an inability of the kidney to elaborate the hormone. That such is the case is suggested by the observation of Verel and others (1959) that following hæmorrhage in a patient with a chronic renal anæmia, regeneration of the red cell mass occurred at a normal rate, but ceased on reaching the original anæmic level.

A further consequence of the hypothesis would be that reduced perfusion of nephrons would constitute a stimulus to erythropoietin production. A fall in blood flow due to increased intrarenal tension in hydronephrosis or in the presence of cysts could account for the unusual phenomenon of pure red cell polycythæmia which may occur with these conditions. The reduced rate of perfusion would lead to a constant underestimation of $c_{c}^{\varrho}$ the oxygen content of the blood, hence constituting: a stimulus to erythropoietin release as in anæmia.os

In polycythæmia vera, where the marrow pro=0 liferation is primary, subnormal secretion of theo hormone would be anticipated. This has now been observed in some instances (Penington, unpublished) but in others, normal or slightlyo elevated erythropoietin titres may occur when the hæmatocrit is particularly high. This presumably. reflects inadequate perfusion of nephrons conse $-\vec{\omega}$ quent on greatly increased viscosity of the blood. Lesions such as hydronephrosis or cysts mighto aggravate the situation in polycythæmia thus? establishing a vicious circle of events, increasediw viscosity of blood providing a stimulus to further $r_{+}^{\infty}$ erythropoiesis. It is of interest that in a case of polycythæmia associated with polycystic kidneys, $\overrightarrow{0}$ Gurney (1960) detected erythropoietin in fluid from one of the cysts. The polycythæmia im-음 proved following nephrectomy, but subsequently relapsed, at which time splenomegaly and elevated ${ }^{\infty}$ leucocyte and platelet counts-hallmarks of poly $\frac{\overline{0}}{\bar{D}}$ cythæmia vera-were noted. In a number of such 3 cases of polycythæmia attributed to renal lesions, splenomegaly or other features of polycythæma vera have been recorded (Lawrence and Dona, 1959), and it would appear likely that in certsin cases the renal lesion aggravates coxistent primary polycythæmia, rather than itself initiating marrows proliferation. In other instances, however, the renal lesion does appear to be the primary cause, as permanent remission has followed surgical removal of the kidney. The reader will find the subject reviewed elsewhere (Gardner and Frey-3 mann, 1958; Lawrence and Donald, 1959; Gurney, I960; Jones, Payne, Hyde and Price, 1960).

\section{Studies on Polycythæmia Accompanyingo Renal Lesions}

Through the kindness of a number of associates, a group of patients has been studied with renaß lesions accompanied by polycythæmia. The de-은 tails of the assay procedure, using rats with sus $\rightarrow$ tained transfusion polycythæmia, will be found? elsewhere (Penington, r96I). The utilization of radioactive iron at 24 hours was $2.8 \%$ of the injected dose in control animals (mean of 25 values $N$ with a standard deviation of \pm 0.84 ). The result of each assay is expressed in terms of multiples of the standard deviation between the mean controlo value and the mean iron utilization of the assayळ animals. Plasma samples were concentrated by a procedure previously reported (Penington, 196r), $\frac{\mathrm{T}}{\bar{O}}$ 
when available in sufficient quantity, and the extract from $12 \mathrm{ml}$. of plasma was injected per assay animal. Alternatively, a total of $4 \mathrm{ml}$. of unmodified plasma was assayed per rat. Normal human plasma or plasma extract under these conditions does not significantly stimulate iron utilization in the assay animals. The statistical significance of each assay result is given in terms of the ' $\mathrm{P}$ ' value calculated by the method for small samples.

\section{Case I-Renal Carcinoma and Red Cell Polycythæmia}

Male, aged 44. Complained of headache and palpitations. Found to have mass in the left loin presumed to be the spleen, a hæmoglobin level of $17.5 \mathrm{~g} . \%$, hæmatocrit $51 \%$, and WBC $11,200 / \mathrm{cu} . \mathrm{mm}$. A diagnosis of polycythæmia vera was made. Twelve months later the patient was referred to Queen Mary's Hospital, Roehampton, where the polycythæmia was found to be associated with a large calcifying carcinoma of the left kidney. At operation the tumour was removed, and the spleen was noted to be normal in size. The patient subsequently became anæmic and deteriorated steadily. Evidence of pulmonary metastases was found and the patient died six weeks after surgery.

\section{Erythropoietin Studies}

Plasma prior to operation (unconcentrated) +8.5 $(\mathrm{P}<0.0 \mathrm{I})$.

Tumour extract (extract from 8 g. per rat) +6.8 $(\mathrm{P}<0.01)$.

\section{Comment}

Both the patient's plasma and the tumour contained highly significant erythopoietic activity. The tumour was heat extracted after homogenization with acetate buffer, $\mathrm{pH} 5.5$, followed by removal of lipids with ether, dialysis and lyophilization. The active material from the tumour is concentrated chemically by the same procedures as the plasma hormone. It is likely that the tumour was itself secreting erythropoietin, which was responsible for the patient's polycythæmia.

\section{Case 2-Hydronephrosis and Red Cell \\ Polycythæmia}

Male, aged 53, was found to have a hæmoglobin of 21 g. $\%$ on routine examination. When seen at the Radcliffe Infirmary, Oxford, he had an enormous mass occupying the left side of the abdomen. The white cell and platelet counts were normal. At operation a very large hydronephrotic kidney was removed and found to be caused by a calculus impacted in the ureter. Three months after operation there was no evidence of recurrence of the polycythæmia.

\section{Erythropoietin Studies}

$$
\begin{aligned}
& \text { Plasma-pre-operative (total dose } \\
& 2.5 \mathrm{ml} \text {.) .. . . } \\
& 4 \mathrm{ml} \text {. } \ldots \quad \ldots \quad \ldots+\mathrm{I} .9(\mathrm{P}=0.05) \\
& \text { Cyst fluid (total dose } 6 \text { mi.) } \quad \ldots \quad+0.5 \quad-
\end{aligned}
$$

\section{Comment}

Despite the small quantity of plasma available for assay prior to operation, significant erythropoietic activity could be detected. A second sample obtained three months after surgery showed a probable slight in- crease in hormone titre above normal; the hæmoglobin had fallen to I I g. $\%$ at this time, and such activity of the plasma would be anticipated, in response to this mild anæmia.

\section{Case 3-Renal Cyst and Red Cell Polycythæmia}

Male, aged 56, admitted to the Edinburgh Royal Infirmary with headache and ataxia, and was found to have a mild polycythæmia confined to the red cell series. The red cell mass was found to be $37.5 \mathrm{ml} / \mathrm{Kg}$. body weight. The spleen was not palpable. An intravenous pyelogram demonstrated a large swelling within the left kidney which at operation proved to be a cyst. The day following operation, signs of vascular damage to the brain stem progressed rapidly, and the patient died. Samples of plasma were obtained from a peripheral vein the evening before surgery, and from the left renal vein during the operation.

\section{Erythropoietin Studies \\ Mixed venous blood (extract from $12 \mathrm{ml} . \quad . \quad \ldots \quad \ldots \quad \ldots+4 . \mathrm{I}(\mathrm{P}<0.0 \mathrm{I})$ \\ Renal vein blood (extract from $12 \mathrm{ml}$.) .. $\quad . \quad \ldots \quad \ldots+2.5(\mathrm{P}<0.05)$}

\section{Comment}

This patient showed erythrocytosis without other features of polycythæmia vera. Plasma obtained before operation showed significant erythropoietic activity, considerably greater than has been found in any subject with polycythæmia vera. Renal vein blood was less active on assay but as it was obtained whilst the patient was under general anæsthesia the two samples are not strictly comparable. The likelihood is that in such cases the hormone is elaborated in increased quantities by the cystic kidney.

\section{Case 4-Polycystic Kidneys and Papilloma of Cæcum with Red Cell Polycythæmia}

Male, aged 53. Attended the Postgraduate Medical School, Hammersmith, complaining of recurrent abdominal pain of three years' duration. Noted to be plethoric but to have a normal blood pressure. The hæmoglobin was 18.0 g. \%, hæmatocrit $51.5 \%$ and white cell and platelet counts normal. An intravenous pyelogram was carried out because of the erythrocytosis, and polycystic kidneys were demonstrated. The abdominal pain remained unexplained.

Two years later the patient again attended hospital with abdominal pain. The hæmatocrit was now $56 \%$; white cells and platelets again normal. The red cell mass was found to be $38.2 \mathrm{ml}$./ Kg. body weight and plasma iron turnover was found to be accelerated. The patient was venesected to a total of $1,120 \mathrm{ml}$. over four days and erythropoietic activity of these samples was determined.

Further investigation revealed that the patient was suffering from a papilliferous tumour of the cæcum which was not evident from previous radiological studies. The tumour was successfully removed and eight months after operation the peripheral blood picture was found to have remained normal in all respects.

\section{Erythropoietin Studies}

Plasma (unconcentrated)-initial 48 hours after $500 \mathrm{ml}$. phlebo48 hours aftr 20 o ml. phlebotomy $\ldots \quad \ldots \quad \ldots \quad \ldots+1.9(P>0.05)$ 


\section{Comment.}

Significantly elevated plasma erythropoietic activity was found prior to phlebotomv but once the hæmoglobin level had been restored to normal, the activity appeared to lessen. The significance of this change is difficult to evaluate. In a normal subject the plasma erythropoietin titre rises after venesection and were the polycythæmia in this patient due to an abnormal ' homostatic setting, by the diseased kidneys, a similar response to venesection would be anticipated. It could be conjectured that the patient initially developed a relative polycythæmia consequent on exudation from the papilliferous tumour, increased viscosity of the blood being sufficient to maintain erythropoietin secretion from the diseased kidneys, and hence perpetuate the polycythæmia.

\section{Case 5-Hydronephrosis with Polycythæmia Vera}

Male, aged 36. Two years before admission developed a painful and discoloured small toe. For six months, troubled by shortness of breath and palpitations on exertion and for two months by a nausea and dull frontal headaches. When admitted to the Radcliffe Infirmary, Oxford, a blood pressure of $150 /$ i $~ 5 \mathrm{~mm}$. $\mathrm{Hg}$. was noted, together with discoloration of two toes and a palpable spleen. The hæmoglobin was 22.0 g. \%, w.b.c. I0,400 cu. mm., and platelets 600,000 and $1,600,000$ on two estimations. An intravenous pyelogram was carried out which showed the right kidney to be enlarged by a space-occupying lesion at the upper pole. This was subsequently demonstrated to be a renal cyst, fluid being aspirated by needle puncture and replaced by radio-opaque dye. The patient was venesected repeatedly until his hæmoglobin and hæmatocrit were restored to normal. However, four months later the polycythæmia had recurred and treatment with radioactive phosphorus was required.

\section{Erythropoietin Studies}

Plasma prior to venesection (dose $4 \mathrm{ml}$.) following venesection (dose $4 \mathrm{ml}$.) .. Cyst fluid (total dose $8 \mathrm{mi}.) \quad \ldots+2.0(\mathrm{P}<0.05)$

\section{Comment}

The plasma erythropoietic activity prior to phlebotomy did just reach a detectable level, but following restoration of the peripheral blood picture to normal, the increase in activity could not be detected. The cyst fluid also showed a barely detectable elevation of erythropoietic activity. The patient was clearly suffexo ing from polycythæmia vera, and similar slight elevatiof of humoral activity in the plasma has now been detected in several patients with this disease in the absence of: renal lesions. The fall in hormone titre following venesection is the opposite to that in the normal subjed and would be consistent with the view that the sligh elevation in hormone secretion is a consequence of the polycythæmia and increased blood viscosity rather tha its primary cause.

\section{Summary}

The anæmia of renal failure cannot be ascribed to a single cause. Shortened red cell life span is found under some circumstances and defective red cell production, the principal factor, mas itself be due to toxic depression of erythropoiesis, in addition to inadequate humoral stimulation of the bone marrow. The kidney plays the majof role in elaboration of erythropoietin in anæmia. although it is not the only site of production of the hormone in the body. A mechanism by which erythropoietin secretion may be related in the kidney to the circulating hæmoglobin level has been outlined and the consequences of this hypo thesis in the interpretation of renal polycythæmi has been discussed.

I am greatly indebted to the following for to publish case reports of patients under their care, providing samples for study, and for furnishing clingeat details: Mr. Rutter, Dr. J. Jeremiah and Mr. Leberne (Case I), Professor Harold Ellis (Case 2), Dr. I. W. Delamore, and Dr. A. F. MacDonald (Case Dr. M. C. Brain (Case 4), Professor L. J. Witts and Dr S. T. Callender (Case 5).

The assays of erythropoietin in polycythæmia reporte耸 above were carried out at The London Hospital. I and indebted to The London Hospital Medical College fo ft the provision of facilities and to Mrs. Isabel Hogarth fo용 technical assistance.

*Previously reported-Ellis, H (1961): Proc. roy. Soc Med., 54, 157.

\section{REFERENCES}

Ashe, B. (1929): Hæmoglobin Percentage and Red Blood Cell Count in Bright's Disease, Myocardial Insufficienc and Hypertension, Arch. intern. Med., 44, 506.

Baldini, M., and LAMPERI, S. (1956): Functional Adaptation of the Kidney in Chronic Anæmia, Minerva nefrol (Torino), 3, I I I.

Borsook, H., Graybiel, A., Keighley, G., and Windsor, E. (I954): Polycythemic Response in Normal Rats to Non-protein Plasma Extract from Anemic Rabbits, Blood, 9, 734.

Bradley, S. E., and Bradley, G. P. (1947): Renal Function During Chronic Anemia in Man, Ibid., 2, I92.

Callen, I. R., and Limarzi, L. R. (1950): Blood and Bone-marrow Studies in Renal Disease, Amer. $\mathcal{F}$. clin. Path. 20, 3 .

Cartwright, G. E., Huguley, C. M., Ashenbrucker, H., FAy, J., and Wintrobe, M. M. (i948): Studies on Freé Erythrocytic Protoporphyrin, Plasma Iron and Plasma Copper in Normal and Anemic Subjects, Blood, 3, 501.

Chaplin, H., and Mollison, P. L. (1953): Red Cell Life-span in Nephritis and in Hepatic Cirrhosis, Clin. Sci., r2, 35 r N

Clotten, A., and Clotten, R. (1959): Untersuchung über die Erythropoietsche Wirkung Polycythämisher Seren⿳亠丷厂 Klin. Wschr., 37, 432.

Cotes, P. M., and Bangham, D. R. (196r): Bio-assay of Erythropoietin in Mice Made Polycythæmic by Exposure to Air at a Reduced Pressure, Nature, I9I, 1065.

Contopoulos, A. N., Ellis, S., Simpson, M. E., Lawrence, J. N., and Evans, H. M. (I954): Production of Polycythemia in Hypophysectomized Rats by the Pituitary Erythropoietic Factor, Endocrinology, 55, 808.

DAmesheK, W. (r935): Biopsy of the Sternal Marrow: Its Value in the Study of Diseases of the Blood Forming Organs Amer. F. med. Sci., rgo, 617. 
Emerson, C. P., and Burrows, B. A. (1949): The Mechanism of Anemia and its Influence on Renal Function in Chronic Uremia, f. clin. Invest., 28, 779.

ERsLev, A. J. (1953): Humoral Regulation of Red Cell Production, Blood, 8, 349.

- (1958): Erythropoietic Function in Uremic Rabbits, Arch. intern. Med., ror, 407.

- (1959): The Effect of Anemic Anoxia on the Cellular Development of Nucleated Red Blood Cells, Blood, 14, 386.

Finch, C. A., Gibson, J. G., Peacock, W. C., and Fluharty, R. G. (1949): Iron Metabolism, Utilization of Radioactive Iron, Ibid., 4, 905.

Fischer, J., and Friederici, L. (196r): Erythropoese bei Bilateral Nephrectomierten Kaninchen, Experientia 17, 318.

Fried, W., Plzak, L., Jacobson, L. O., and Goldwasser, E. (1957): Studies on Erythropoiesis: III. Factors Controlling Erythropoietin Production, Proc. Soc. exp. Biol. (N.Y.), 94, 237.

Gallagher, N. I., McCarthy, J. M., and Lange, R. D. (1960): Observations on Plasma Erythropoietic Stimulating Factor in the Plasma of Uremic and Non-uremic Anemic Patients, Ann. intern. Med., 52, I 201.

GardNer, F. H., and FreymanN, J. G. (1958): Erythrocythemia and Hydronephrosis: Report of a Case with Radioiron Studies, with Recovery after Nephrectomy, New Engl. F. Med., 259, 323.

Gingold, N., Comsa, G., and Roman-Crivat, A. (1938): Anemie Pseudo-regenerative Comme Syndrome Terminal chez un Azotemique Chronique, Sang, 12, 543.

Goldwasser, E., Fried, W., and Jacobson, L. O. (I958): Studies on Erythropoiesis: VIII. The Effect of Nephrectomy on Response to Hypoxic Anoxia, F. Lab. clin. Med., 52, 375.

- (1962): in 'Proceedings of Conference on Erythropoietin and Erythropoietic Mechanisms', San Francisco. In press.

Gordon, A. S., Piliero, S. J., and Tannenbaum, M. (1955): Erythropoietic Activity of Blood and Tissues of Anemic Rabbits, Amer. F. Physiol., 181, 585 .

Gurney, C. W. (1960): Erythemia in Renal Disease, Trans. Ass. Amer. Phycns., 73, 103.

Jacobson, L. O., Plzak, L., Fried, W., and Goldwasser, E. (1956): Plasma Factors Influencing Red Cell Production, Nature, 177, 1240.

— Goldwasser, E., Fried, W., and Plzak, L. (1957): Role of the Kidneys in Erythropoiesis, Ibid., 179, 633.

- -, Marks, E. K., Gaston, E. O., and Goldwasser, E. (1959): Studies on Erythropoiesis: XI. Reticulocyte Response of Transfusion-induced Polycythemic Mice to Anemic Plasma from Nephrectomized Mice and to Plasma from Nephrectomized Rats Exposed to Low Oxygen, Blood, 14, 635.

Jones, N. F., Payne, R. W., Hyde, R. D., and Price, T. M. L. (I960): Renal Polycythæmia, Lancet, i, 299.

Joske, R. A., McAlister, J. M., and Prankerd, T. A. J. (1956): Isotope Investigations in Red Cell Production and Destruction in Chronic Renal Disease, Clin. Sci., 15, 511 .

Kuratowska, Z., Lewartowski, B., and Michalak, E. (196r): Studies on the Production of Erythropoietin by Isolated Perfused Organs, Blood, 18, 527.

Lawrence, J. H., and Donald, W. G. (1959): Polycythemia and Hydronephrosis or Renal Tumors, Ann. intern. Med., 50, 959 .

Linman, J. W., and Bethell, F. H. (I957): The Plasma Erythropoietic-stimulating Factor in Man: Observations on Patients with Polycythemia Vera and Secondary Polycythemia, F. Lab. clin. Med., 49, I 13.

LOgE, J. P., LANGE, R. D., and Moore, C. V. (1950): Characterization of the Anemia of Chronic Renal Insufficiency, f. clin. Invest., 29, 830 .

- - - - (1958): Characterization of the Anemia Associated with Chronic Renal Insufficiency, Amer. F. Med., 24, 4 .

Mirand, E. A., and Prentice, T. C. (I957): Presence of Plasma Erythropoietin in Hypoxic Rats With and Without Kidneys and Spleen, Proc. Soc. exp. Biol. (N.Y.), 96, 49.

Muirhead, E. E., STIRMan, J. A., and Jones, F. (1960): Renal Auto-explantation and Protection Against Reno-prival Hypertensive Cardiovascular Disease and Hemolysis, $\mathcal{F}$. clin. Invest., 39, 266.

NAETS, J. P. (1958): The Kidney and Erythropoiesis, Nature, 182, 1516.

(1960): Erythropoietic Factor in Kidney Tissue of Anemic Dogs, Proc. Soc. exp. Biol. (N.Y.), ro3, 129.

Nordenson, N. G. (1938): The Bone Marrow in the Anæmia of Chronic Nephritis, Folia Hamat. (Lpz.), 59, I.

Osnes, S. (1958): An Erythropoietic Factor Produced by the Kidney, Brit. med. F., ii, 1387.

(1959): Experimental Study of an Erythropoietic Factor Produced in the Kidney, Ibid., ii, 650.

Parsons, L., and Ekola-Strolberg, M. (1933): Anemia in Azotemia, Amer. F. med. Sci., 185, 181 .

Penington, D. G. (196I): The Role of the Erythropoietic Hormone in Anæmia, Lancet, i, 30I.

(1962): in 'Proceedings of Conference on Erythropoietin and Erythropoietic Mechanisms'. In press.

Rambach, W. A., Alt, H. L., and Cooper, J. A. D. (1957): The Mode of Action and Nature of a Heat-stable Plasma Erythropoietic Factor, Blood, 12, I 101.

,--1, (1961): Erythropoietic Activity of Tissue Homogenates, Proc. Soc. exper. Biol. (N.Y.), ro8, 793.

Rees, S. B., Scheitlin, W. G., Pond, J. C., McManus, J., Gurld, W. R., and Merrill, J. P. (1957): Effect of Dialysis and Purine Ribosides Upon the Anemia of Uremia, . clin. Invest., 36, 923.

, - Giordano, G., Guild, W. R., and Merrill, J. P. (r960): 'Proc. Ist Intern. Congr. Nephrol., Geneva/ Evian, p. 559. Basel: Karger.

Reichlin, M., and Harrington, W. J. (1960): Studies in Erythropoietin: I. Demonstration of Erythropoietin in Normal Plasma, Blood, r6, 1298.

Reissman, K. R., Nomura, T., GunN, R. W., and Brosius, F. (1960): Erythropoietic Response to Anemia or Erythropoietin in Uremic Rats With or Without Functioning Renal Tissue, Blood, 16, 141 I.

(I962): in 'Proceedings of Conference on Erythropoietin and Erythropoietic Mechanisms'. In press.

Schwarz, S. O., and Motto, S. A. (1949): The Diagnostic Significance of 'Burr' Red Blood Cells, Amer. F. med. Sci., 218, 563 .

ScotT, R. B. (1939): Sternal Puncture in the Diagnosis of Diseases of the Blood-forming Organs, Quart. F. Med., N.S., 8, 127.

Simpson, M. E., Evans, E. S., and Rosenberg, L. L. (1959): Re-evaluation of the Evidence for a Pituitary Erythropoietic Hormone, Endocrinology, 64, 592. 
Stohlman, F., Rath, C. E., and Rose, J. C. (1954): Evidence for a Humoral Regulation of Erythropoiesis, Blood,

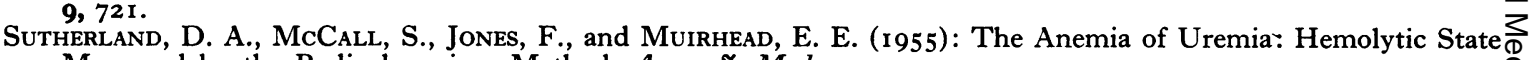
Measured by the Radiochromium Method, Amer. F. Med., 19, 153.

Van Dyke, D. C., Layrisse, M., Lawrence, J. H., Garcia, J. F., and Pollycove, M. (1961): Relation Between Severity.. of Anemia and Erythropoietic Titre in Human Beings, Blood, 18, 187.

Verel, D., Turnbull, A., Tudhope, G. R., and Ross, J. H. (1959): Anæmia in Bright's Disease, Quart. F. Med., $\stackrel{\overrightarrow{\vec{S}}}{\overrightarrow{\vec{*}}}$ N.S., 28, 491 .

Yen Hoong Loo, Cheng-Chun Lee, and Flemming, M. (1960): Erythropoietic Activity of Proteolytic Enzymes, Proc. Soc. exp. Biol. (N.Y.), 104, 39. 